\title{
Adaptability of Moringa oleifera Lam. (Horseradish) Tree Seedlings to Three Temperature Regimes
}

\author{
Quintin E. Muhl, Elsa S. du Toit, Petrus J. Robbertse
}

Department of Plant Production and Soil Science, University of Pretoria, Pretoria, South Africa.

Email: quintin.muhl@up.ac.za

Received August 12 $2^{\text {th }}, 2011$; revised September 22 ${ }^{\text {nd }}, 2011$; accepted October $24^{\text {th }}, 2011$.

\begin{abstract}
Moringa oleifera trees are naturally found in tropical climates around the world, while the extent of their adaptability to cooler climates was the main objective of this study. A total of 264 trees, made up of an equal number hardened and non-hardened seedlings were randomly assigned to three temperature-controlled greenhouses each with a different fluctuating night/day temperature regime (TR) namely; $10 / 20^{\circ} \mathrm{C} \pm 2{ }^{\circ} \mathrm{C}, 15 / 25^{\circ} \mathrm{C} \pm 2{ }^{\circ} \mathrm{C}$ and $20 / 30^{\circ} \mathrm{C} \pm 2{ }^{\circ} \mathrm{C}$. During the 32-week trial period, biweekly measurements of tree height, stem diameter and leaf area estimates of each individual tree within all three temperature regimes (TRS) were taken. The $20 / 30^{\circ} \mathrm{C}$ TR was the most favorable towards overall tree growth, as the highest values were obtained across most measured parameters. The increase in temperature resulted in growth rate increases of over $650 \%$ between the $10 / 20^{\circ} \mathrm{C}$ and $20 / 30^{\circ} \mathrm{C}$ and over $250 \%$ between the $10 / 20^{\circ} \mathrm{C}$ and $15 / 25^{\circ} \mathrm{C}$ night/day TRS. The hardening-off pre-treatment increased both final tree height and stem diameter, resulting in increases of $3.09 \times\left(10 / 20^{\circ} \mathrm{C}\right), 1.44 \times\left(15 / 25^{\circ} \mathrm{C}\right)$ and $1.23 \times\left(20 / 30^{\circ} \mathrm{C}\right)$ compared to their non-hardened off counterparts. Although the average leaf area increased with the increase in TR and remained higher for the duration of the trial, cycles of regular leaf drop and renewed flushes were prevalent at both the $15 / 25^{\circ} \mathrm{C}$ and $20 / 30^{\circ} \mathrm{C}$ temperature treatments.
\end{abstract}

Keywords: Hardening-Off, Biodiesel, Growth Rate

\section{Introduction}

Moringa oleifera Lam. also known as Horseradish tree is one of 14 different species belonging to the family Moringaceae. Although indigenous to the sub-Himalayan regions in northwestern India, it is currently found in numerous countries situated in the tropical and sub-tropical regions across Africa, South East Asia and South America (Jahn, 1988) [1]. M. oleifera is a fast growing, small to medium sized tree ranging between 5 to $12 \mathrm{~m}$ in height. The tree is evergreen in tropical, while deciduous in sub-tropical climates. The tree canopy has an umbrella shaped crown with bi-(tri-)pinnate leaves, while the individual leaflets have a leaf area of one to two $\mathrm{cm}^{2}$. Flowers are white to cream colored and zygomorphic. The tree bears 20 to $30 \mathrm{~cm}$ long fruit that once mature, change colour from green to brown revealing numerous round or triangular seeds with three papery wings (Folkard, et al., 1999) [2]. Amongst the most common uses for M. oleifera such as animal forage, nutrition, medicine and water purification, the seed also contains a multipurpose, non-drying oil. One of the uses for this oil is the production of biofuel, in the form of biodiesel (Rashid et al., 2008) [3]. Biodiesel is a renewable fuel source that is obtained through the process of transesterification where natural plant oils are transformed into a fuel, which can be used in conventional diesel engines (Poeet, 2006) [4]. Since M. oleifera plantations of 3270 trees/ha can yield anything between 991 - 3303 liters of oil per hectare, depending on the soil and environmental conditions, it can effortlessly compete with several other oil crops in terms of liters of oil per hectare (Fuglie, 2001) [5]. Although $M$. oleifera is grown throughout numerous African countries, no evidence of large-scale commercial plantings have been reported, possibly as a result of the limited scientific data that is currently available on both the propagation and cultivation of the tree. 


\section{Materials and Methods}

Growth performance trials were conducted at Phytotron Section on the Experimental Farm of the University of Pretoria $\left(25^{\circ} 45^{\prime} \mathrm{S}, 28^{\circ} 16^{\prime} \mathrm{E}\right)$ at an altitude of $1372 \mathrm{~m}$ above sea level.

Trees for the purpose of this trial were grown from seeds sourced from wild M. oleifera trees in Malawi. Seeds were planted and germinated in seedling trays containing Hygromix ${ }^{\mathrm{TM}}$, a sterile, soilless growing medium for seedlings, manufactured by Hygrotech Seed (Pty) Ltd. After germinating seed under favorable green-house conditions between $20^{\circ} \mathrm{C}-25^{\circ} \mathrm{C}$ for one week, half the seedlings were left in the greenhouse, while the other half was hardened-off by placing them outside where the average minimum/maximum temperatures fluctuated between $15 / 30^{\circ} \mathrm{C}$. Both treatments were irrigated to fieldcapacity every second day. Equal numbers of hardenedoff (132) and non-hardened-off (132) seedling-trees were randomly selected and transplanted into 10 liter black plastic bags, five weeks after seed was planted into seedling trays. These bags were filled with a commercial bark potting medium manufactured by Braaks (Pty) Ltd. Trees were placed onto benches inside temperature-controlled greenhouses. The abovementioned 264 trees were equally divided and randomly assigned to three different temperature regimes TRS namely, $10 / 20^{\circ} \mathrm{C} \pm 2^{\circ} \mathrm{C}, 15 / 25^{\circ} \mathrm{C} \pm$ $2^{\circ} \mathrm{C}$ and $20 / 30^{\circ} \mathrm{C} \pm 2^{\circ} \mathrm{C}$, simulating night/day temperature fluctuations and exposed to natural daylight. The average photosynthetic active radiation (PAR) at 12:00 in the afternoon on a clear day, inside the temperaturecontrolled greenhouses was measured at $1350 \mu \mathrm{mol} \cdot \mathrm{m}^{-2} \cdot \mathrm{s}^{-1}$. To adjust nitrogen deficiencies evident from soil analysis results, $20 \mathrm{~g}$ of LAN (28) fertilizer was applied to each tree, 16 weeks after trial commencement. Irrigation was manually applied three times a week until field-capacity was reached, as the excess water was able to drain from bags.

Bi-weekly measurements of tree height $(\mathrm{mm})$, measured with a measuring tape and stem diameter $(\mathrm{mm})$, measured at soil level with a calliper were made of each tree for the duration of the 32-week trial.

The total leaf area estimates of each tree were calculated according to a non-destructive method of leaf area index (LAI) calculation described by Siegfried et al. (2007) [6]. Firstly, the number of tripinnate leaves as well as the number of leaflets on the youngest mature leaf of each tree was counted. Secondly, the number of leaflets per leaf was multiplied with the number of leaves per tree to provide an estimate for the number of leaflets per tree. Then, leaflets were randomly sampled from the three temperature treatments and measured with a LI3100 , Licor leaf area meter to provide an estimated leaf area $\left(\mathrm{cm}^{2}\right)$ of the individual leaflets. Finally the average leaf area of a single leaflet was multiplied with the estimated number of leaves per tree to provide an approximate leaf area per tree.

Data collected over the 32-week trial period were statistically analyzed using the Statistical Analysis System (SAS Version 9.1) program for Microsoft Windows, by the Statistics Department at the University of Pretoria. The Analysis of Variance (ANOVA) was performed, together with F-test (Steele and Torrie, 1980) [7] to enable the comparison between treatment means.

\section{Results and Discussion}

The difference in average tree height and stem diameter of both hardened-off ( $\mathrm{HO}$ ) and non-hardened-off (NHO) trees within each temperature regime (TR) for the 32week trial duration is illustrated in Figure 1. Amongst the three TRS investigated in this trial, the $20 / 30^{\circ} \mathrm{C}$ TR clearly was the most favorable for tree growth, with a final average tree height of $1970 \mathrm{~mm}$ and stem diameter of $28.4 \mathrm{~mm}$. Growth at the $15 / 25^{\circ} \mathrm{C}$ TR was significantly less with a final average tree height and stem diameter of $1100 \mathrm{~mm}$ and $16.1 \mathrm{~mm}$ respectively. The $10 / 20^{\circ} \mathrm{C}$ regime was certainly not conducive to $M$. oleifera growth as hardly any noticeable growth occurred throughout the 32-week period. This TR limited the average final tree height to $480 \mathrm{~mm}$ and stem diameter to $8.8 \mathrm{~mm}$. The effect of the fertilizer application during week 16 was responsible for the sudden change in growth line gradient. It is also noticeable how fertilizer use efficiency varied between the three TRS, while the increase in growth rate was highest at the $20 / 30^{\circ} \mathrm{C}$ regime, the $10 / 20^{\circ} \mathrm{C}$ regime revealed only a slight increase in response to the fertilizer application (Figure 1).

The final growth between the HO and NHO seedlings at all three TRS for both the tree height as well as the stem diameter was not significantly different (Figure 1). However, the growth rates between the HO and NHO seedlings for both these parameters differed among and within the three TRS as illustrated in Table 1. In addition the percentage increase in growth rate, increased with a decrease in TR, exemplifying the importance of hardening off seedlings especially if seedlings are to be transplanted into a cooler climate. Regardless of the final growing climate, the $\mathrm{HO}$ seedlings are at an advantage and therefore the hardening-off process is highly recommended for M. oleifera trees.

The hardening-off process involves several complex processes that have an effect on numerous morphological and physiological mechanisms enhancing plant growth under unfavorable environmental conditions (VillarSalvador et al., 1999) [8]. Amongst numerous other plants, the effect of hardening seedlings prior to transplanting were studied on Rosmarinus officinalis and $\mathrm{Ne}$ rium oleander by Sánchez-Blanco et al. (2004) [9] and 

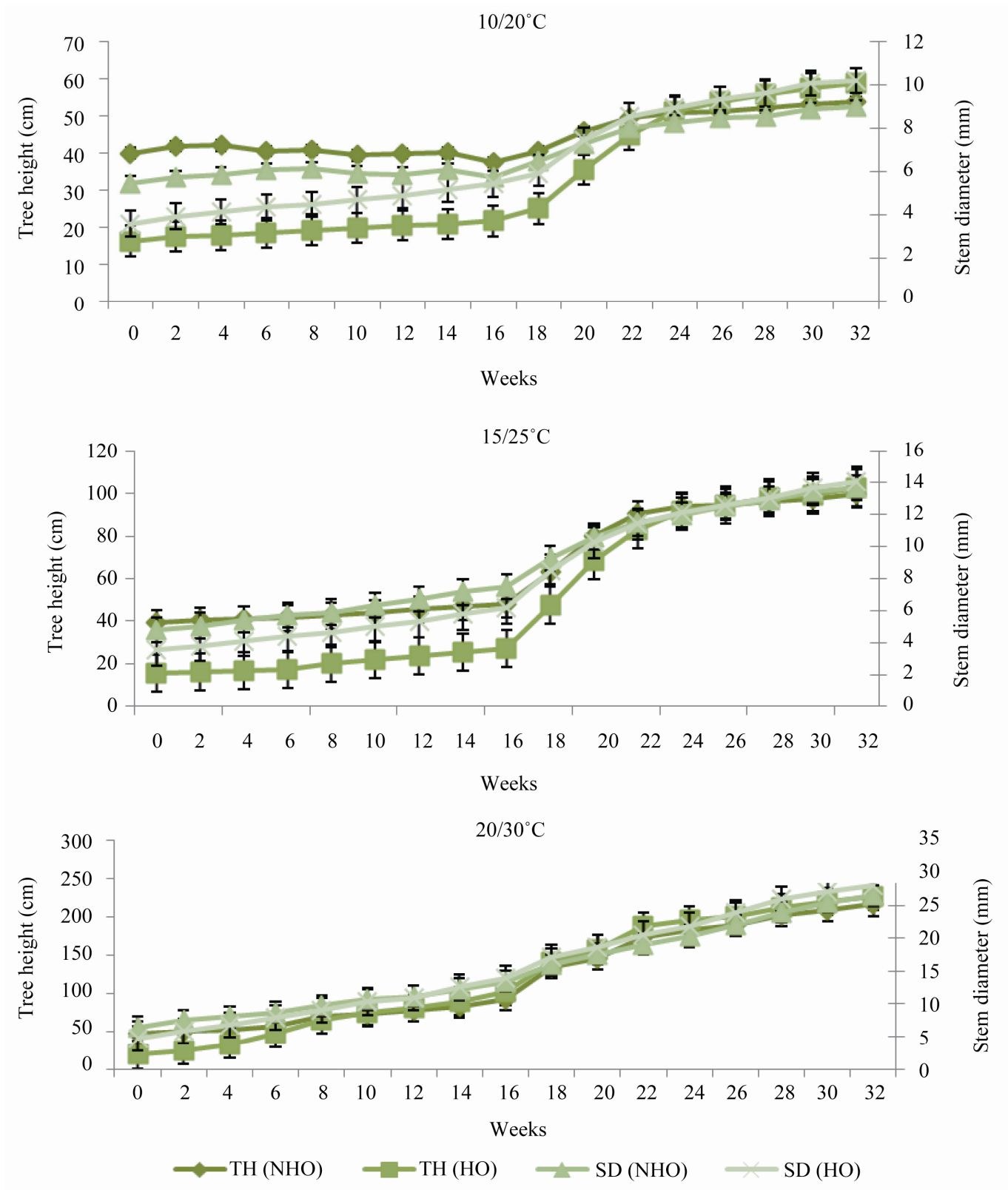

Figure 1. Differences in average tree height $(\mathrm{cm})$ and stem diameter $(\mathrm{mm})$ of Moringa oleifera cultivated from both hardened-off and non-hardened-off seedlings at various temperature regimes over a 32-week period. Vertical bars represent LSD. NHO_non-hardened-off, HO_hardened-off, TH— tree height and SD—stem diameter.

Table 1. Differences in average growth rate $(\mathrm{mm} / \mathrm{week})$ between the temperature regimes and hardening-off treatments over the 32-week trial period. Different letters indicate significant differences at $P \leq 0.05$ according to the F-test. NHO-non-hardened-off, HO — hardened-off.

\begin{tabular}{|c|c|c|c|c|c|c|}
\hline \multirow{3}{*}{ Pre-treatment } & \multicolumn{6}{|c|}{ Growth rate (mm/week) } \\
\hline & \multicolumn{2}{|c|}{$10 / 20^{\circ} \mathrm{C}$} & \multicolumn{2}{|c|}{$15 / 25^{\circ} \mathrm{C}$} & \multicolumn{2}{|c|}{$20 / 30^{\circ} \mathrm{C}$} \\
\hline & Tree height & Stem diameter & Tree height & Stem diameter & Tree height & Stem diameter \\
\hline NHO & $4.33^{\mathrm{a}}$ & $0.11^{\mathrm{g}}$ & $18.86^{\mathrm{c}}$ & $0.28^{\mathrm{i}}$ & $52.94^{\mathrm{e}}$ & $0.63^{\mathrm{k}}$ \\
\hline HO & $13.36^{\mathrm{b}}$ & $0.21^{\mathrm{h}}$ & $27.12^{\mathrm{d}}$ & $0.33^{\mathrm{j}}$ & $65.08^{\mathrm{f}}$ & $0.73^{1}$ \\
\hline Average & $8.85^{\mathrm{ab}}$ & $0.16^{\mathrm{gh}}$ & $22.99^{\text {cd }}$ & $0.30^{\mathrm{ij}}$ & $59.01^{\mathrm{m}}$ & $0.68^{\mathrm{n}}$ \\
\hline
\end{tabular}


Bañon et al. (2006) [10] respectively. Both these papers reported the superiority of the hardened (HO) plants over their non-hardened (NHO) counterparts upon the exposure to unfavorable environmental growing conditions (Sánchez-Blanco et al. 2004 [9]; Bañon et al. 2006 [10]).

The growth rates between the various TRS, as shown in Table 1, were significantly different $(P \leq 0.05)$, in which a $10^{\circ} \mathrm{C}$ increase between the $10 / 20^{\circ} \mathrm{C}$ and $20 / 30^{\circ} \mathrm{C}$ in the night/day TR caused a tree growth rate increase of over $650 \%$ in tree height and $400 \%$ in stem diameter. While the $5^{\circ} \mathrm{C}$ difference between the $10 / 20^{\circ} \mathrm{C}$ and $15 /$ $25^{\circ} \mathrm{C}$ TR resulted in a tree height and stem diameter growth rate increases of over $250 \%$ and $200 \%$ respectively. The increase in vegetative growth of $M$. oleifera trees brought about by the increase in TR agrees with similar observations made in several other tropical and subtropical trees (Menzel and Paxton, 1985 [11]; Trochoulias and Lahav, 1983 [12]; George and Nissen, 1987 [13]; Utsunomiya, 1992 [14]), such as mango (Whiley et al., 1989 [15]), macadamia (Lahav and Trochoulias, 1982 [16]) and lychee (Menzel and Paxton, 1985 [11]).

According to Downs and Hellermers (1975) [17], temperature affects both physical and metabolic processes within plants, by altering the reaction rates of enzyme systems, since the optimum temperatures for enzymatic reactions are enzyme specific, and only vary between enzymatic systems. The highest growth rates are only achieved once the environmental temperature coincides with the requirements of these enzymatic reactions. As the enzymatic reactions responsible for the processing of photosynthates are temperature sensitive, growth and development are a function of the growing temperature. Temperature extremes would therefore lead to atypical and reduced growth.

The optimum TR for the purposes of this study evi- dently is the $20 / 30^{\circ} \mathrm{C} \mathrm{TR}$, as it produced the highest growth across all measured parameters. However, according to Downs and Hellermers (1975) [17], tropical trees that reach their maximum cardinal temperature, often manifest this through rapid stem elongation, thin leaves and reduced dry matter production at the expense of reproductive development. Observations of the above symptoms under the $20 / 30^{\circ} \mathrm{C} T R$, suggest that any further increases in temperature would most likely decrease growth. Compared to the $20 / 30^{\circ} \mathrm{C}$ TR, growth was significantly reduced at the $15 / 25^{\circ} \mathrm{C} \mathrm{TR}$, while hardly any growth was observed at the low $10 / 20^{\circ} \mathrm{C}$ TR. It can therefore be assumed that the threshold temperature for growth of $M$. oleifera trees is within the $10^{\circ} \mathrm{C}-20^{\circ} \mathrm{C}$ range. This not only verifies the fact that $M$. oleifera favors tropical growing environments as stated by Morton (1991) [18] and Mughal et al. (1999) [19], but also demonstrates the reluctance of $M$. oleifera to acclimatize and generate satisfactory growth under cooler climates.

Similarly to the temperature effect on both tree height and stem diameter, the average leaf area $\left(\mathrm{cm}^{2}\right)$ increased with an increase in TR (Figure 2). However, the increase in leaf area was less steady, as fluctuations in leaf area occurred due to repeated cycles of leaf drop followed by renewed flushes. The extent of these fluctuating leaf area measurements intensified with an increase in TR and was the most volatile under the $20 / 30^{\circ} \mathrm{C}$ regime. The $15 / 25^{\circ} \mathrm{C}$ treatment also showed volatility, but to a lesser extent than the $20 / 30^{\circ} \mathrm{C}$ treatment. The $10 / 20^{\circ} \mathrm{C}$ was the most stable, showing a slight but constant increase of leaf area over the 32-week trial period.

\section{Conclusions}

Growth of $M$. oleifera is evidently favoured by high growing temperature of $>25^{\circ} \mathrm{C}$, confirming the prefer-

Total leaf area

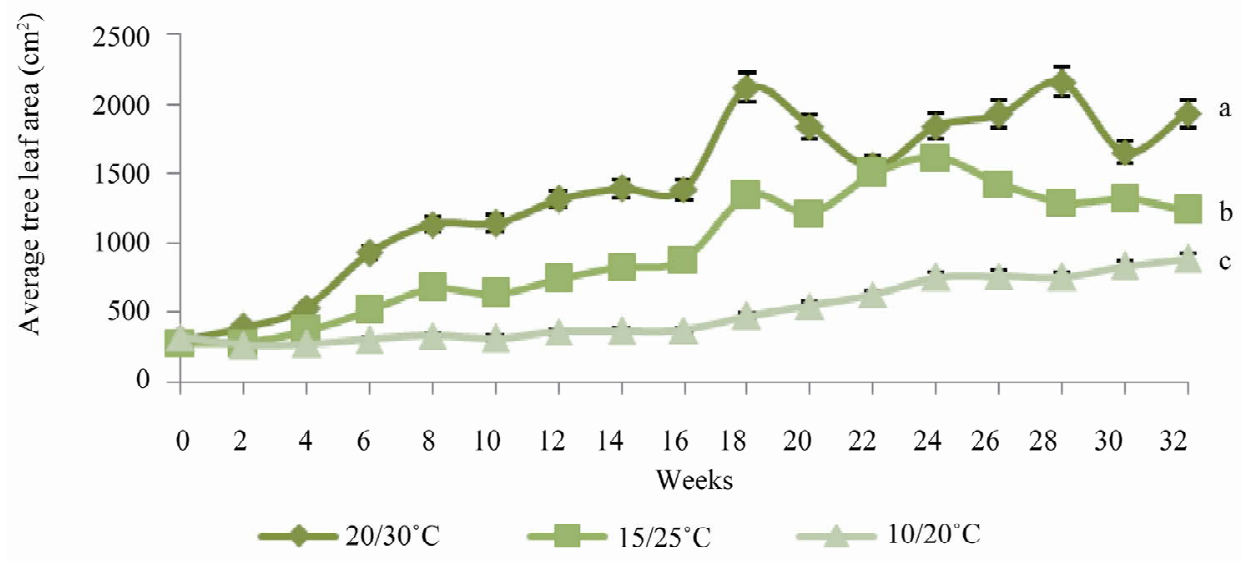

Figure 2. Increase in average tree leaf area $\left(\mathrm{cm}^{2}\right)$ of Moringa oleifera trees at three temperature regimes over a 32-week period. Treatment means with letters in common are not significantly different at $\boldsymbol{P} \leq 0.05$. Vertical bars represent LSD. 
ence of M. oleifera towards tropical growing environments. This was confirmed by the temperature treatment results, where trees at the $20 / 30^{\circ} \mathrm{C}$ TR revealed the highest growth rates for both tree height and stem thickening. In addition, the $20 / 30^{\circ} \mathrm{C}$ temperature treatment, although variable, consistently had the highest leaf area over the entire trial period. As the effect of additional, higher TRS were not investigated in this study, the possibility of improved growth at even higher temperatures cannot be excluded. Tropical climates are therefore ideal for the cultivation of $M$. oleifera, however satisfactory growth during the hot summer months in sub-tropical climates is achievable, if the winters are mild, as trees are frost tender. The hardening-off of the seedlings prior to transplanting has proven to increase the growth rate of both tree height and stem diameter across all three TRS. The hardening off process is highly recommended for $M$. oleifera trees, especially if intended cultivation is in below optimal temperature environments.

\section{REFERENCES}

[1] S. A. A. Jahn, "Using Moringa oleifera Seeds as Coagulant in Developing Countries," Journal of the American Water Works Association, Vol. 80, No. 6, 1988, pp. 43-50.

[2] G. Folkard, J. Sutherland and R. Shaw, "Water Clarification Using Moringa oleifera Coagulant. Water and Environmental Health at London and Loughborough (WELL)," Loughborough University, Loughborough, 1999, pp. 109112.

[3] U. Rashid, F. Anwar, B. R. Moser and G. Knothe, "Moringa oleifera Oil: A Possible Source of Biodiesel," Bioresource Technology, Vol. 99, No. 17, 2008, pp. 81758179. doi:10.1016/j.biortech.2008.03.066

[4] M. D. Poeet, "Biodiesel Crop Implementation in Hawaii," Hawaii Agricultural Research Center, Hawaii, 2006, pp. 5-10.

[5] L. J. Fuglie, "The Miracle Tree, the Multiple Attributes of Moringa," Church World Service, Dakar, 2001, p. 85.

[6] W. Siegfried, O. Viret, B. Huber and R. Wohlhauser, "Dosage of Plant Protection Products Adapted to Leaf Area Index in Viticulture," Crop Protection, Vol. 26, No. 2, 2007, pp. 73-82. doi:10.1016/j.cropro.2006.04.002

[7] R. G. D. Steele and J. H. Torrie, "Principles and Procedures of Statistics," 2nd Edition, McGraw-Hill, New York, 1980.

[8] P. Villar-Salvador, L. Ocaña, J. Peñuelas and I. Carrasco, "Effect of Water Stress Conditioning on the Water Relations, Root Growth Capacity, and the Nitrogen and Nonstructural Carbohydrate Concentration of Pinus halepensis Mill. (Aleppo Pine) Seedlings," Annals of Forest Science, Vol. 56, No. 6, 1999, pp. 459-465.

\section{doi:10.1051/forest: 19990602}

[9] M. J. Sánchez-Blanco, T. Ferrández, A. Navarro, S. Bañon and J. J. Alarcón, "Effects of Irrigation and Air Humidity Preconditioning on Water Relations, Growth and Survival of Rosmarinus officinalis Plants during and after Transplanting," Journal of Plant Physiology, Vol. 161, No. 10, 2004, pp. 1133-1142. doi:10.1016/j.jplph.2004.01.011

[10] S. Bañon, J. Ochoa, J. A. Franco, J. J. Alarcón and M. J. Sánchez-Blanco, "Hardening of Oleander Seedlings by Deficit Irrigation and Low Air Humidity," Environmental and Experimental Botany, Vol. 56, No. 1, 2006, pp. 3643. doi:10.1016/j.envexpbot.2004.12.004

[11] C. M. Menzel and B. F. Paxton, "The Effect of Temperature on Growth and Dry Matter Production of Lychee Seedlings," Scientia Horticulturae, Vol. 26, No. 1, 1985 , pp. 17-23. doi:10.1016/0304-4238(85)90097-4

[12] T. Trochoulias and E. Lahav, "The Effect of Temperature on Growth and Dry-Matter Production of Macadamia," Scientia Horticulturae, Vol. 19, No. 1-2, 1983, pp. 167176. doi:10.1016/0304-4238(83)90058-4

[13] A. P. George and R. J. Nissen, "The Effects of Day/Night Temperatures on Growth and Dry Matter Production of Custard Apple (Annona cherimola $\times$ Annona squamosa,) Cultivar African Pride," Scientia Horticulturae, Vol. 31, No. 3-4, 1987, pp. 269-274. doi:10.1016/0304-4238(87)90052-5

[14] N. Utsunomiya, "Effect of Temperature on Shoot Growth, Flowering and Fruit Growth of Purple Passionfruit (Passiflora edulis Sims var. edulis)," Scientia Horticulturae, Vol. 52, No. 1-2, 1992, pp. 63-68. doi:10.1016/0304-4238(92)90008-Z

[15] A. W. Whiley, T. S. Rasmussen, J. B. Saranah and B. N. Wolstenholme, "Effect of Temperature on Growth, Dry Matter Production and Starch Accumulation in Ten Mango (Mangifera indica L.) Cultivars," Journal of Horticultural Science, Vol. 64, No. 6, 1989, pp. 753-766.

[16] E. Lahav and T. Trochoulias, "The Effect of Temperature on Growth and Dry Matter Production of Avocado Plants,' Australian Journal of Agricultural Research, Vol. 33, No. 3, 1982, pp. 549-558. doi:10.1071/AR9820549

[17] R. J. Downs and H. Hellermers, "Environment and the Experimental Control of Plant Growth," Academic Press Inc., London, 1975.

[18] J. F. Morton, "The Horseradish Tree, Moringa pterigosperma (Moringaceae). A Boon to Arid Lands?" Economic Botany, Vol. 45, No. 3, 1991, pp. 318-333.

[19] M. H. Mughal, G. Ali, P. S. Srivastava and M. Iqbal, "Improvement of Drumstick (Moringa pterygosperms Gaertn.)-A Unique Source of Food and Medicine through Tissue Culture," Hamdard Medical, Vol. 42, No. 1, 1999, pp. 37-42. 